\title{
Effect of Yeast Assimilable Nitrogen Content on Fermentation Kinetics, Wine Chemical Composition and Sensory Character in the Production of Assyrtiko Wines
}

\author{
Stefania Christofi $^{1}$, Seraphim Papanikolaou ${ }^{1}$, Maria Dimopoulou ${ }^{1} \mathbb{D}$, Antonia Terpou ${ }^{1,2}$ (D), \\ Ionel Bogdan Cioroiu ${ }^{3}$, Valeriu Cotea ${ }^{4}$ (D) and Stamatina Kallithraka ${ }^{1, *}$ D
}

\section{check for}

Citation: Christofi, S.; Papanikolaou,

S.; Dimopoulou, M.; Terpou, A.;

Cioroiu, I.B.; Cotea, V.; Kallithraka, S. Effect of Yeast Assimilable Nitrogen Content on Fermentation Kinetics, Wine Chemical Composition and Sensory Character in the Production of Assyrtiko Wines. Appl. Sci. 2022, 12, 1405. https://doi.org/10.3390/ app12031405

Academic Editor: Daniela Isola

Received: 30 November 2021

Accepted: 25 January 2022

Published: 28 January 2022

Publisher's Note: MDPI stays neutral with regard to jurisdictional claims in published maps and institutional affiliations.

Copyright: (C) 2022 by the authors. Licensee MDPI, Basel, Switzerland. This article is an open access article distributed under the terms and conditions of the Creative Commons Attribution (CC BY) license (https:// creativecommons.org/licenses/by/ $4.0 /)$.
1 Department of Food Science and Human Nutrition, Agricultural University of Athens, 75, Iera Odos, 11855 Athens, Greece; stefania.christofi@gmail.com (S.C.); spapanik@aua.gr (S.P.); maroula.dimo@hotmail.com (M.D.); aterpou@agro.uoa.gr (A.T.)

2 Department of Agricultural Development, Agri-Food, and Natural Resources Management, School of Agricultural Development, Nutrition \& Sustainability, National and Kapodistrian University of Athens, 34400 Evripos Union, Greece

3 Romania Academy-Iasi Branch, Research Centre for Oenology, 9 M. Sadoveanu Alley, 700490 Iasi, Romania; bogdan.cioroiu@gmail.com

4 Department of Oenology, Iasi University of Life Sciences, 3 M. Sadoveanu Alley, 700490 Iasi, Romania; vcotea@uaiasi.ro

* Correspondence: stamatina@aua.gr

\begin{abstract}
Two wild-type Saccharomyces cerevisiae yeast strains (Sa and $\mathrm{Sb}$ ) were tested for white wine production using Assyrtiko grape of Santorini. A third commercial Saccharomyces strain was also studied for comparison reasons. Two concentrations of yeast extract and diammonium phosphate (DAP) were added to the must $(150$ and $250 \mathrm{mg} / \mathrm{L})$ in order to evaluate the effect of nitrogen content on the final wine quality. Analytical methods (HPLC, GC-MS) and sensory analysis were employed to assess the quality of the wines. Fermentation kinetics were monitored throughout the experiment. By the second day of fermentation, all strains showed an approximate consumption of $70 \%$ of amino acids. Differences among strains were observed regarding inorganic nitrogen requirements. Sb strain resulted in higher concentrations of higher alcohols (1.9-fold) and ketones (5.6-fold) and lower concentrations of esters (1.2-fold) compared to the control, while Sa strain resulted in higher content of fatty acids (2.1-fold). Both indigenous strains scored better results in aroma quality, body and acidity compared to control. The overall evaluation of the data highlights the great potential of the indigenous $S$. cerevisiae strains as fermentation starters providing promising results in the sector of terroir wines.
\end{abstract}

Keywords: yeast assimilable nitrogen content (YAN); wine fermentation starters; indigenous Saccharomyces cerevisiae; wine volatile compounds; wine organoleptic quality; terroir wines

\section{Introduction}

In the past few years, radical changes in global wine exports have occurred, creating a new era in production and consumption of wine [1]. Targeting national competitive advances, producers have focused on the production of terroir wines, using indigenous grape varieties and autochthonous yeast strains [2]. In the industrial wine sector, selected yeast and bacterial strains are employed for fermentation, targeting high yields of productivity, stress tolerance, unique aromatic characteristics and positive sensory attributes $[3,4]$.

Growth and fermentation kinetics of yeasts are influenced by their nutritional requirements and are highly strain-dependent [5]. Nitrogen availability in grape must is a key parameter for the wine fermentation process, since $\mathrm{N}$ - is a substantial nutrient element for yeast growth. It affects the formation of yeast biomass, which, in turn, regulates fermentation duration and kinetics [5]. Grape must contains several different nitrogen sources 
including amino acids, ammonium, and small peptides, although not all of these forms can be metabolized by yeasts. The ammonium and the $\alpha$-amino acid nitrogen forms are described as the preferential forms, while utilization of small peptides in different environments is possible under specific conditions [6]. A minimum of $140 \mathrm{mg} / \mathrm{L}$ of assimilable nitrogen has been established as essential for yeast growth in must under anaerobic fermentation conditions [5,7]. The assimilation rate of nitrogen is strictly strain-dependent, and as a result, the selected strain plays a major role in alcoholic fermentation kinetics [8]. Different S. cerevisiae strains are characterized by unique nitrogen uptake requirements resulting in variable fermentation behaviors and unique wine organoleptic profiles [9]. Previous studies revealed that different yeast strains can show sufficient fermentation capacity even with limited amounts of nitrogen, while other strains require higher amounts and may result in stuck fermentations in case of nitrogen deficiency $[5,10]$. In order to avoid nitrogen deficiency during wine fermentation, it is a common practice to supplement musts with inorganic nitrogen mainly in the form of diammonium phosphate (DAP). This nitrogen source has been linked with significant effects on wine flavor [11-13]. More specifically, the type of nitrogen source directly affects the production of wine volatiles (esters, alcohols, and volatile fatty acids) as well as glycerol and organic acid composition [12-14]. Likewise, nitrogen-containing compounds are considered as important precursors of wines' volatile compounds, and as a result, the origin and availability of nitrogen significantly affects the final quality of wine [11].

The aim of the current study was to investigate the potential of two S. cerevisiae strains (previously isolated from Santorini Island), to produce wine with unique organoleptic characteristics. For this purpose, must from the Assyrtiko grape variety (indigenous to Santorini Island), were fermented with the autochthonous yeasts. Aiming to produce wines of high quality, the fermentation performance of the yeasts under two YAN contents (high and low) was evaluated, and their impact on wine sensory character was assessed.

\section{Materials and Methods}

\subsection{Microorganisms and Growing Conditions}

Commercial and autochthonous yeast strains were studied as starter cultures for winemaking. The yeast Saccharomyces cerevisiae $\mathrm{Sa}$ and $\mathrm{Sb}$ autochthonous strains from the private collection of the Agricultural University of Athens (Laboratory of Food Microbiology \& Biotechnology, Department of Food Science and Human Nutrition, Athens, Greece), which had never been tested before regarding their fermentative activity, were used as starter cultures for fermentation of Assyrtiko grape must from Santorini Island (Greece). These strains were deposited to the private collection of the Laboratory of Food Microbiology \& Biotechnology-Agricultural University of Athens, Greece, obtaining the code numbers FMCC Y73 and FMCC Y74, respectively. The identification of the yeast species was verified by sequencing of the D1/D2 domain of 26S rRNA gene [15] (data not shown). The commercial S. cerevisiae strain, iYeast ${ }^{\circledR}$ Passion Fruit (LaFood, Fasano, Italy) was chosen as a control inoculation, as this strain is suitable for the production of white wines with strong aromatic intensity.

Yeast strains were stored at $-80{ }^{\circ} \mathrm{C}$ in vials with glycerol $(30 \%)$ and were activated by adding $200 \mu \mathrm{L}$ to $10 \mathrm{~mL}$ yeast peptone dextrose $(20 \mathrm{~g} / \mathrm{L}$ glucose, $10 \mathrm{~g} / \mathrm{L}$ yeast extract and $10 \mathrm{~g} / \mathrm{L}$ peptone) medium at $28^{\circ} \mathrm{C}$ for $24 \mathrm{~h}$, while the purity of each strain was verified via optical microscopy [16]. Pre-cultures were performed in $250 \mathrm{~mL}$ flasks filled with $50 \mathrm{~mL}$ of medium (YPD medium: $20 \mathrm{~g} / \mathrm{L}$ glucose, $10 \mathrm{~g} / \mathrm{L}$ yeast extract, $10 \mathrm{~g} / \mathrm{L}$ peptone, $\mathrm{pH} \approx 3.5$ ) previously autoclaved at $\mathrm{T}=115^{\circ} \mathrm{C}$ at $1.5 \mathrm{~atm}$ for $15 \mathrm{~min}$.

\subsection{Vinification}

Wine was produced with Assyrtiko from Santorini Island (Santo Wines, Union of Santorini cooperatives, Pyrgos Santorini, Greece) in duplicate. The grapes were mechanically crushed and pressed at $8{ }^{\circ} \mathrm{C}$. The must was left for $12 \mathrm{~h}$ for clarification at $4{ }^{\circ} \mathrm{C}$ without any addition of enzymes. After clarification, free sulphur dioxide $\left(\mathrm{SO}_{2}\right)$ of the 
must was adjusted to $10 \mathrm{mg} / \mathrm{L}$, and filtration $(0.45 \mu \mathrm{m}$ filters $)$ was applied to eliminate the presence of autochthonous yeast cells. The initial concentration of reducing sugars was $210 \mathrm{~g} / \mathrm{L}$, pH was 3.15, total acidity had a value of $5.2 \mathrm{~g} / \mathrm{L}$ (expressed as tartaric acid), and yeast assimilable nitrogen (YAN) was $80 \mathrm{mg} \mathrm{N} / \mathrm{L}(50 \mathrm{mg} / \mathrm{L}$ in the form of $\alpha$-amino acids and the remaining $30 \mathrm{mg} / \mathrm{L}$ in the form of ammonium nitrogen). Enrichment of the musts with YAN was carried out with addition of equal contents of yeast extract and DAP (diammonium phosphate), until respective concentrations of 150 and $250 \mathrm{mg} \mathrm{N} / \mathrm{L}$ were achieved. These two concentrations were chosen, as the minimum (150 mg N/L) to avoid sluggish or stuck fermentations and the most commonly found ( $250 \mathrm{mg} \mathrm{N} / \mathrm{L})$ for industrial fermentations [17]. The three yeast strains were inoculated at $10^{6} \mathrm{cfu} / \mathrm{mL}$ to initiate alcoholic fermentations in 4 - $\mathrm{L}$ vessels, at $18{ }^{\circ} \mathrm{C}$ in biological duplicates. The fermentation rate was monitored daily by recording the density of the must [18]. Sugar concentration (glucose and fructose) was determined through HPLC in a Waters Association 600E apparatus equipped with an RI detector (Waters 410, Midland, ON, Canada) [4]. The fermentations were monitored for 25 days, until the wild type strains reached the levels of dry wines $(<4 \mathrm{~g} / \mathrm{L}$ of sugars), and to avoid further oxidation of the produced wines even though the concentrations of sugars in fermentations contacted with the commercial strain were slightly higher.

\subsection{Chemical Analysis of Must and Wines}

Classic parameters of wines (free and total $\mathrm{SO}_{2}$ contents, $\%$ vol., $\mathrm{pH}$, titratable and volatile acidity, $\mathrm{A}_{420 \mathrm{~nm}}$ ) were determined according to the international methods of the International Organization of Vine and Wine (OIV) [19]. Nitrogen of $\alpha$-amino acid was determined as described by Dukes and Butzke, (1998) [17], while ammonium nitrogen was determined according to Aerny (1996) [20].

Glycerol and acetic acid were quantified through high-performance liquid chromatography/HPLC (Waters Association 600E apparatus) with an RI detector (Waters 410, Midland, ON, Canada) and an ion exclusion column (Aminex HPX-87H, Bio-Rad, CA, USA). The column temperature was set at $65{ }^{\circ} \mathrm{C}$ with a flow rate of $0.8 \mathrm{~mL} / \mathrm{min}$. The mobile phase was $\mathrm{H}_{2} \mathrm{SO}_{4}$. For quantitative analysis, standard solutions of glycerol and acetic acid (Sigma-Aldrich Ltd., Taufkirchen, Germany) were prepared in pure water (Milli-Q, Merk, Taufkirchen, Germany) and wine samples were injected directly into the column. Determinations were performed by means of standard curves [16].

The amino-acid analysis was performed using a liquid chromatographic-triplequadrupole mass spectrometric method. Analyses were performed on a Thermo Ultimate 3000 ultra-high pressure liquid chromatograph consisting of a 1000 pressure pump, degasser, PAL open-autosampler, and valve interface module. The detection system consisted of a Thermo Quantum Access Max triple-quadrupole mass spectrometer, and for the evaluation, a multiple reaction monitoring option was used. Chromatographic separation was performed in an Intrada Aminoacid (mixed mode, normal phase and ion exchange) column, particle size $3 \mu \mathrm{m}(150 \times 4.6 \mathrm{~mm})$, thermostated at $45{ }^{\circ} \mathrm{C}$ through the binary gradient shown in Table 1 (phase A, 74:16:10:0.2 mixture of isopropanol, $25 \mathrm{mM}$ ammonium formate, acetonitrile, and formic acid; phase B, 20:80 mixture of acetonitrile and $100 \mathrm{mM}$ ammonium formate) and a flow rate $0.35 \mathrm{~mL} / \mathrm{min}$. For detection, triple-quadrupole mass spectrometry with spray voltage $3000 \mathrm{~V}$, vaporizer temperature $350^{\circ} \mathrm{C}$, sheath gas pressure $35 \mathrm{psi}$, ion sweep gas pressure $0.0 \mathrm{psi}$, aux gas pressure $10 \mathrm{psi}$, capillary temperature $380^{\circ} \mathrm{C}$, and capillary offset $35 \mathrm{v}$ was used. The target compounds were identified according to the retention times and the characteristic ions from molecular ion fragmentation.

Table 1. Eluent gradient for UPLC determination of amino acids.

\begin{tabular}{ccccccc}
\hline Time (min) & $0-12$ & $12-17$ & $17-19$ & $19-31$ & $31-31.5$ & $31.5-35$ \\
Eluent A (\%) & 100 & 97 & 0 & 0 & 100 & 100 \\
Eluent B (\%) & 0 & 3 & 100 & 100 & 0 & 0 \\
\hline
\end{tabular}


The identification of the headspace volatiles of produced wines was conducted by means of gas chromatography/mass spectrometry (GC/MS) using the solid phase microextraction method (SPME). GC/MS analysis was performed on a GCMS-QP2010 Ultra (Shimadzu Inc., Japan) system set at $240{ }^{\circ} \mathrm{C}$ in split mode (split ratio 1/20) [21]. The conditions of headspace SPME sampling were as follows: $2 \mathrm{~mL}$ of wine sample, $7.5 \mathrm{~mL}$ of deionized water, $1 \mathrm{~g}$ ammonium sulfite, and $500 \mu \mathrm{L}$ internal standard (1-octanol) were transferred into a $20 \mathrm{~mL}$ headspace vial fitted with a polytetrafluoroethylene (PTFE)-lined silicone septum. The sealed wine samples were initially stirred $(250 \mathrm{rpm})$ in a tap bath $\left(\mathrm{T}=40{ }^{\circ} \mathrm{C}\right.$ ) for $5 \mathrm{~min}$ (Thermodyne-Nuova II; stir speed 5) to achieve the appropriate temperature, and then the SPME fiber (DVB/CAR/PDMS, $2 \mathrm{~cm}$; Sigma Aldrich, Germany) was exposed to the headspace for $30 \mathrm{~min}$. The separation of wine volatile compounds took place in a DB-Wax capillary column $(30 \mathrm{~m} \times 0.25 \mathrm{~mm}$ i.d., $0.25 \mu \mathrm{m}$ film thickness, Agilent, USA). Helium was used as the carrier gas at a constant linear velocity of $36 \mathrm{~cm} / \mathrm{s}$. The oven temperature was set at $40^{\circ} \mathrm{C}$ for $5 \mathrm{~min}$ and increased by $5{ }^{\circ} \mathrm{C} / \mathrm{min}$ up to $180{ }^{\circ} \mathrm{C}$, and subsequently by $30^{\circ} \mathrm{C} / \mathrm{min}$ up to $240^{\circ} \mathrm{C}$. The oven temperature was finally stated at $240{ }^{\circ} \mathrm{C}$ for $5 \mathrm{~min}$. Source and interface temperatures were set at $200^{\circ} \mathrm{C}$ and $240^{\circ} \mathrm{C}$, respectively. For each sample during the elution of ethanol, which was expected at 3.4-4.0 min [22], the filament was programmed to turn off targeting to extend its life, as ethanol was expected at much higher rates compared to other volatiles. Molecular identification of volatile compounds was carried out using AMDIS (v. 2.65) software based on retention time and mass spectra and peak area of each compound, respectively.

\subsection{Sensory Analysis}

Sensory assessment was performed, for all wines, by a group of 12 trained panelists with previous experience in wine analysis using the Pivot@ profile sensory method [23]. Twenty-five $\mathrm{mL}$ of the samples and the pivot wine (prepared with the commercial yeast strain) were presented in a completely randomized order to each panelist, marked with three-digit code, at $16{ }^{\circ} \mathrm{C}$. The wines produced with $\mathrm{Sa}$ and $\mathrm{Sb}$ were compared with pivot wine. All samples were expectorated, and tap water was provided for mouth-rinsing between samples. The attributes selected were grouped in two categories: olfactive descriptors (floral, fruity, reduction, vinegary, odor of oxidation) and gustative descriptors (sourness and mouthfeel as the perception of the body of wine). The panelists also performed an overall odor quality assessment. All samples were evaluated in triplicate.

\subsection{Statistical Analysis}

Analysis of variance (ANOVA) was performed using Statistica V.7 (Statsoft Inc., Tulsa, OK, USA) to determine whether the mean values of the parameters differed between treatments. Tukey's HSD was used as comparison tests when samples were significantly different after ANOVA $(p<0.05)$.

\section{Results \& Discussion}

\subsection{Effect of YAN Content on Fermentation Kinetics}

The kinetics of alcoholic fermentations depended mostly on the yeast strains and secondarily on YAN concentrations. The $S$. cerevisiae strain Sa consumed half of the reducing sugars after 4 days of fermentation. In contrast, the commercial and Sb strains were characterized by a $48 \mathrm{~h}$ delay, consuming half of the concentration of reducing sugars on the 6 th fermentation day. Furthermore, Sa managed to reach the levels of residual sugars $(3.6 \mathrm{~g} / \mathrm{L})$ corresponding to dry wine on the 25 th day, while the $\mathrm{Sb}$ and the commercial strain ended up with 4.0 and $4.5 \mathrm{~g} / \mathrm{L}$, respectively. Despite the initial, somehow higher total sugar consumption rate and subsequently ethanol production rate of the commercial strain compared to the new isolates (Sa and $\mathrm{Sb}$ ), finally, the ethanol content of the three wines produced did not show any statistically important differences (final ethanol content $\sim 100 \mathrm{~g} / \mathrm{L}=12.9 \% v / v$ ) (Figure 1). The conversion yield of ethanol produced per unit of total sugars consumed was c. $0.50-0.51 \mathrm{~g} / \mathrm{g}$ (the absolute value of the slope of the line) for all 
strains tested, that is, $98-100 \% w / w$ (Figure 2 ) of the maximum theoretical yield $(=0.51 \mathrm{~g} / \mathrm{g}$ ), demonstrating the potential of the employed wild type strains for the production of wines containing high concentrations of ethanol [16]. No significant differences were observed regarding the conversion yield of ethanol between ferments of the same strain provided with different initial YAN. This outcome could indicate that the relatively low fermentation temperature and the yeast strain pose a more significant role compared to YAN $[24,25]$.

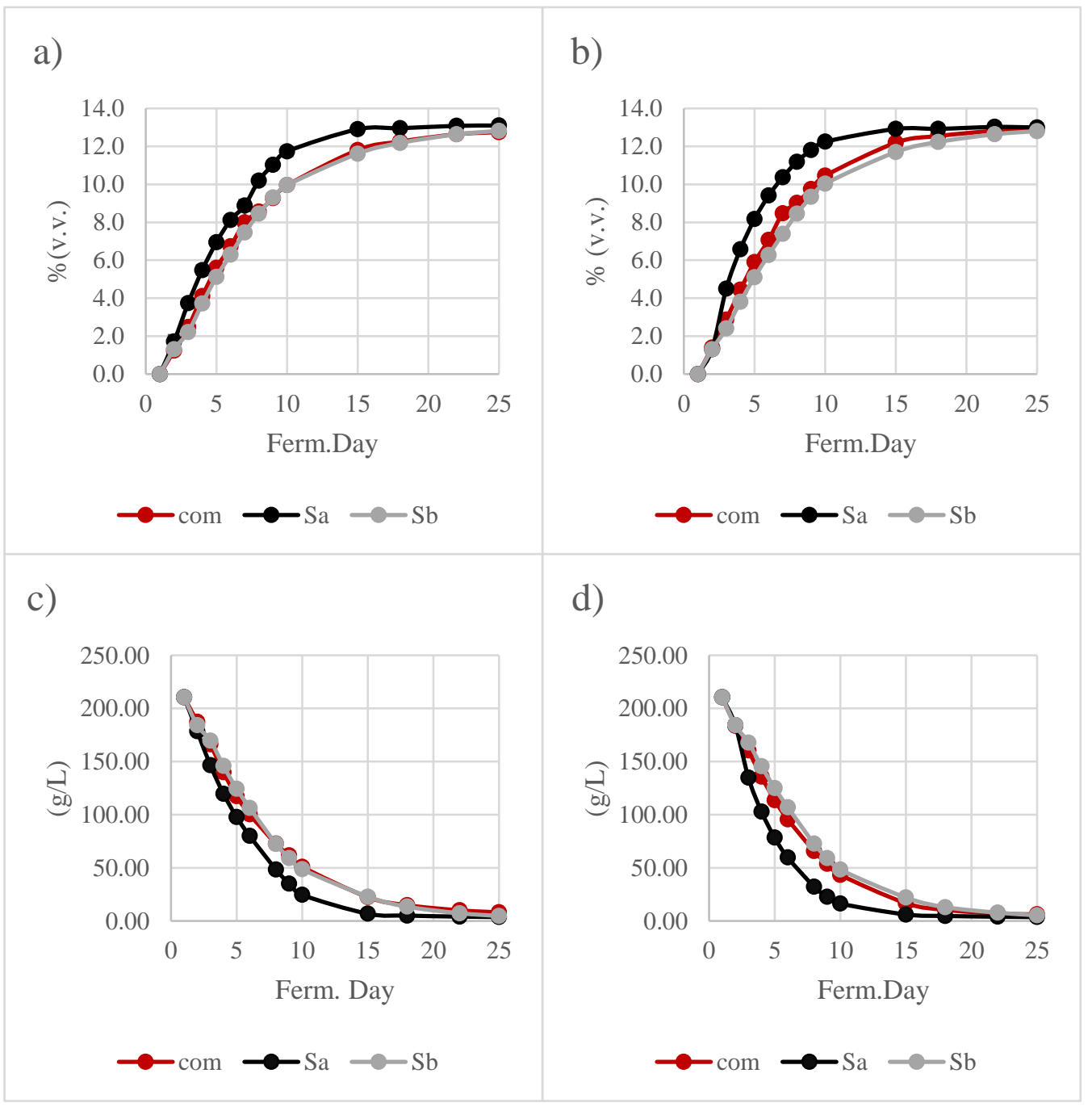

Figure 1. Production of ethanol by S. cerevisiae in fermentations with (a) low and (b) high concentrations of YAN and consumption of reducing sugars by S. cerevisiae in fermentations with (c) low and (d) high concentrations of YAN. Red, black and grey lines correspond to samples fermented with the commercial, Sa and Sb strains, respectively.

Apart from the differences in fermentation kinetics, the strains showed variations in the consumption of fructose and glucose (Figure 3). The commercial strain presented a clear preferential uptake of glucose. Once glucose was almost depleted, there was a sharp increase in fructose uptake. As previously reported, this outcome was expected on the growth face, where actively growing cells present a preferential affinity for glucose. After this stage, the consumption rates of both glucose and fructose were noted to be similar. Furthermore, in case of the existence of two separate sugar transport systems, these results may indicate that both systems are capable of transporting either sugar, but only if the preferred sugar is not present. In the case of a common transport system, competitive inhibition of fructose uptake by glucose could have taken place [26]. However, this pathway was not confirmed in the present study, as the two sugars were consumed 
almost simultaneously at different rates (Figure 3). This could be an indication of two separate transport systems with distinct kinetic properties. Furthermore, no significant differences concerning glucose and fructose uptake were observed between fermentations with different initial YAN, as nitrogen content in both cases was sufficient and prevented reduction in glucose uptake capacity [27], while must sugar content did not pose a limiting factor in nitrogen availability and requirements [28].

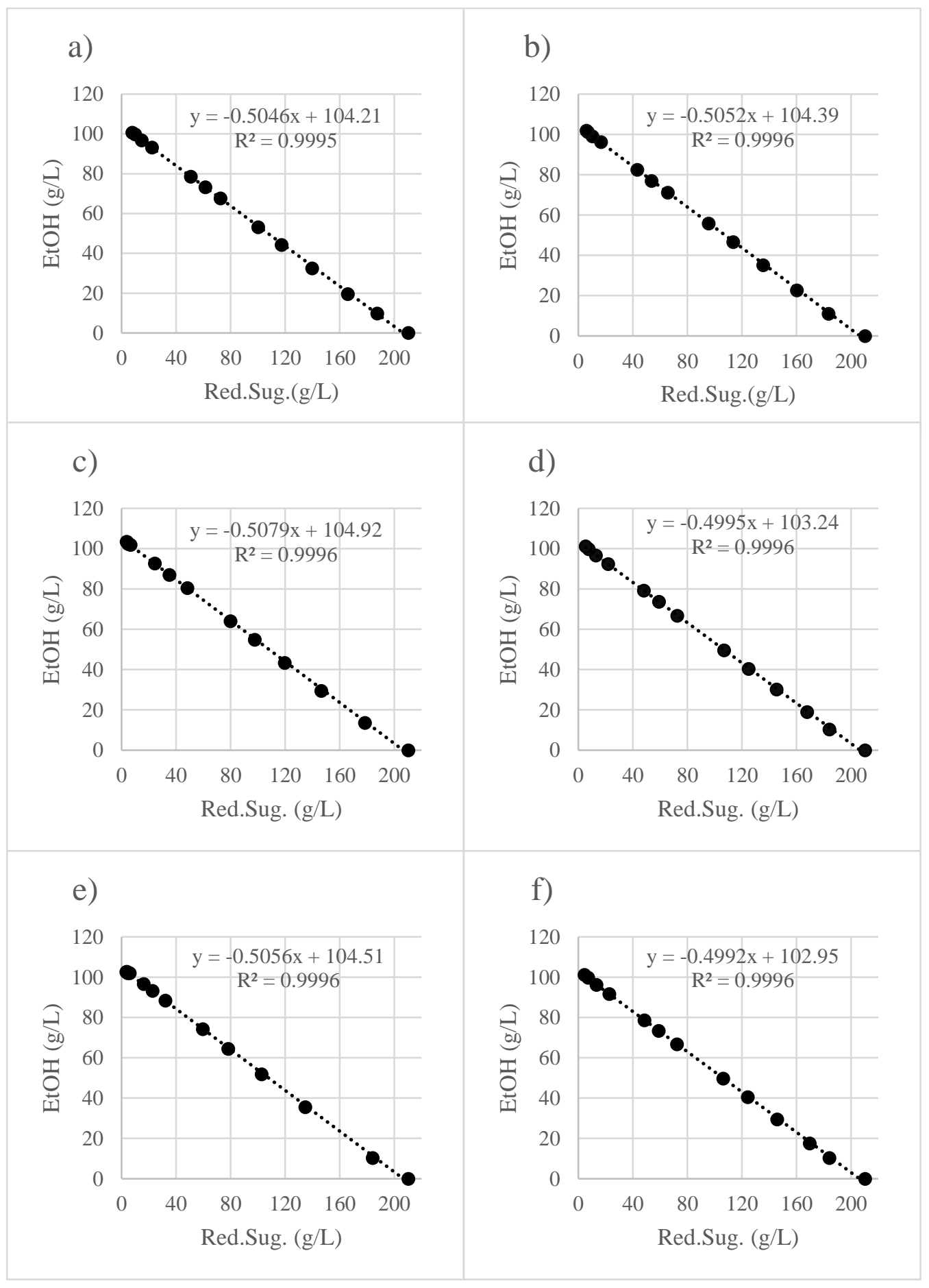

Figure 2. Conversion yield of ethanol produced per unit of total sugars consumed by the commercial strain in fermentations with (a) low and (b) high concentrations of YAN, Sa in fermentations with (c) low and (d) high concentrations of YAN, and $\mathrm{Sb}$ in fermentations with (e) low and (f) high concentrations of YAN. 


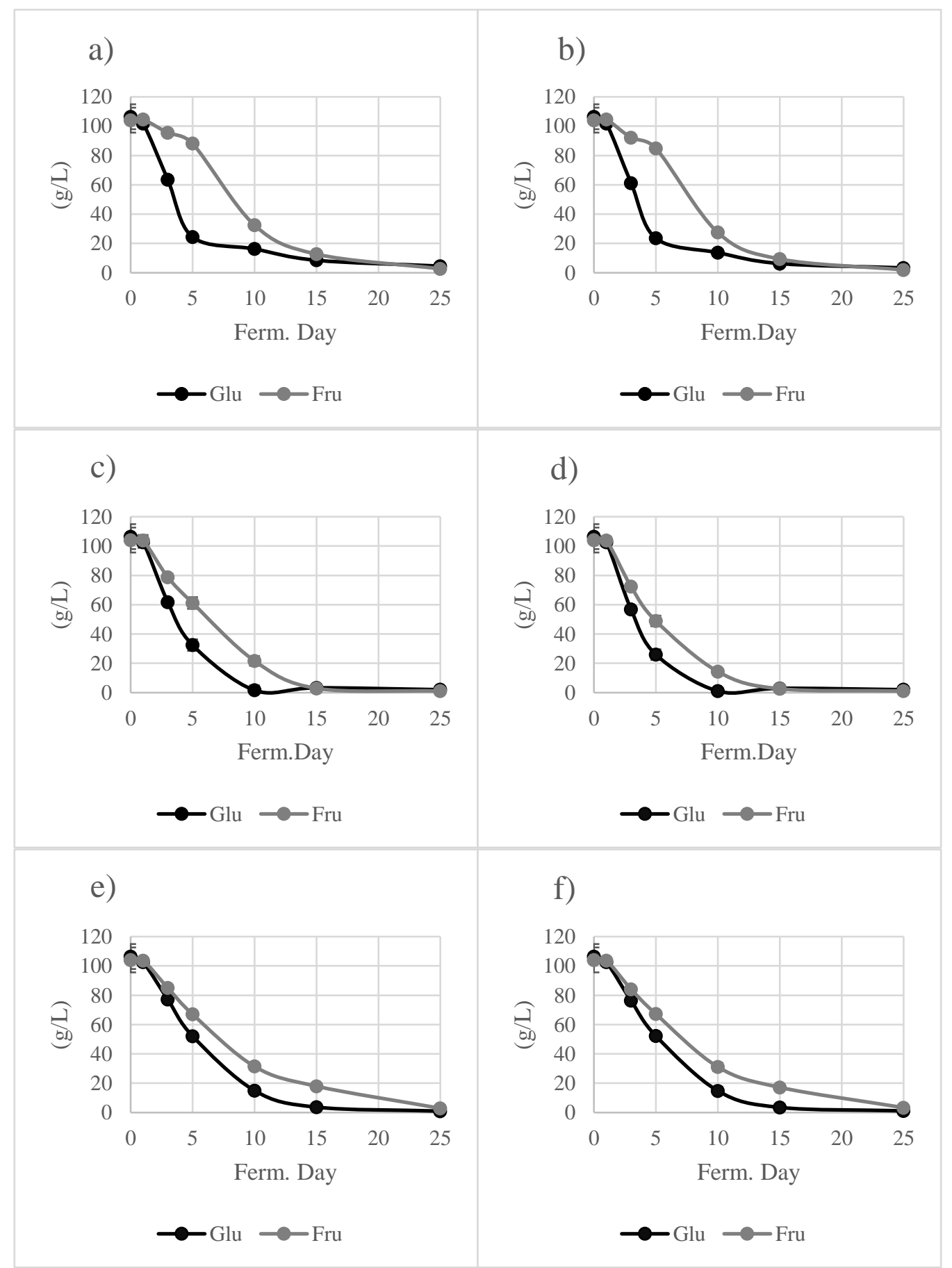

Figure 3. Consumption of glucose and fructose by commercial strain in fermentations with (a) low and (b) high concentrations of YAN, Sa in fermentations with (c) low and (d) high concentrations of YAN, and $\mathrm{Sb}$ in fermentations with (e) low and (f) high concentrations of YAN. Black and grey lines correspond to glucose and fructose consumption, respectively.

Regarding sugar utilization, differences in inorganic nitrogen requirements were observed among the different $S$. cerevisiae strains. Sa strain consumed ammonium nitrogen $\left(\mathrm{NH}_{4}{ }^{+}\right)$faster, especially in the case of ferments containing $150 \mathrm{mg} \mathrm{N} / \mathrm{L}$. In those cases, ammonia was exhausted by the 3rd day of fermentation (data not shown). Sb strain showed a completely different behavior regarding ammonium nitrogen consumption. In the case of musts containing $250 \mathrm{mg} \mathrm{N} / \mathrm{L}$, the $\mathrm{NH}_{4}{ }^{+}$consumption speed was higher, even though complete exhaustion of ammonia was achieved on the 6th day of fermentation. On the 
other hand, in musts inoculated with $\mathrm{Sb}$, containing $150 \mathrm{mg} \mathrm{N} / \mathrm{L}$, ammonia was exhausted by the 5 th day of fermentation (data not shown). Based on these observations, Sa strain seems to exhibit higher $\mathrm{NH}_{4}{ }^{+}$requirements than the other strains examined, while $\mathrm{Sb}$ and commercial strains might be characterized by comparable $\mathrm{NH}_{4}{ }^{+}$demands (Figure 4 a).

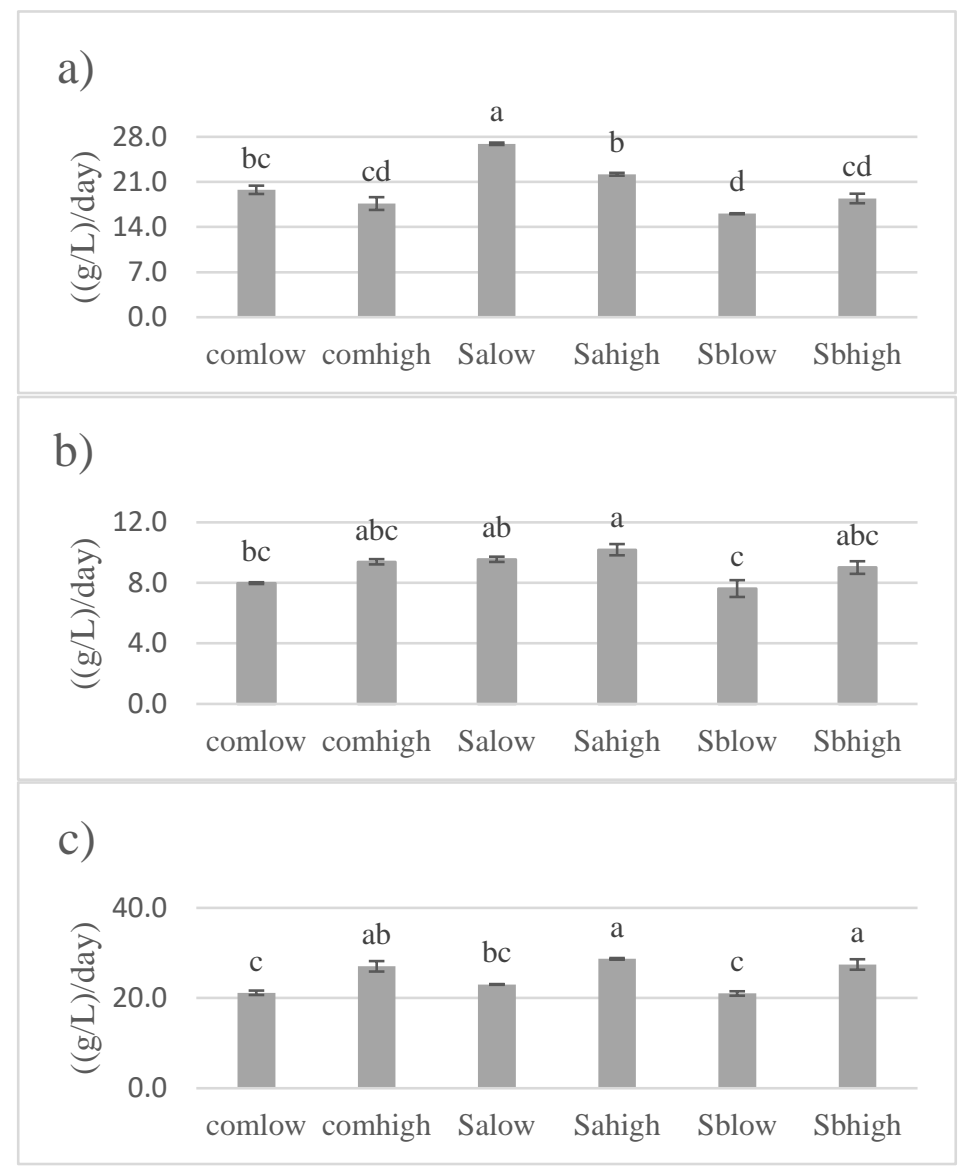

Figure 4. Utilization rate of (a) NH4+, (b) FAN and (c) YAN by three different $S$. cerevisiae strains. The 'low' and 'high' correspond to fermentations with $150 \mathrm{mg} \mathrm{N} / \mathrm{L}$ and $250 \mathrm{mg} \mathrm{N} / \mathrm{L}$ of initial YAN, respectively. The 'com', 'Sa' and 'Sb' correspond to fermentations carried out with the commercial and $\mathrm{Sa}$ and $\mathrm{Sb}$ strains, respectively. Values followed by different letters in each column indicate significant differences $(p<0.05)$ among different samples.

In addition, all three S. cerevisiae tested strains exhausted approximately $70 \%$ of $\alpha$ amino acids (FAN) by the second day of fermentation. More specifically, consumption of FAN in musts inoculated with the commercial, Sa and Sb strains, reached $69.1 \%, 73.7 \%$ and $59.6 \%$, respectively. The FAN utilization followed $\mathrm{NH}_{4}{ }^{+}$consumption in a nitrogen catabolite repression manner. The fastest consumption of $\mathrm{NH}_{4}{ }^{+}$in ferments inoculated with Sa strain compared to the Sb strain, probably lead to a faster activation of the GAP1 (general amino acid permease) and GLN3 (activated when preferred nitrogen sources are not available) proteins. The activation of the specific proteins leads the metabolic pathway to non-preferred nitrogen sources (FAN) [29]. Once again, the Sb strain was characterized by the lowest nitrogen depletion speed, indicating the lowest FAN demand (Figure $4 \mathrm{~b}$ ). In general, the utilization rate was higher in the trials containing $250 \mathrm{mg} \mathrm{N} / \mathrm{L}$, compared to fermentations containing $150 \mathrm{mg} \mathrm{N} / \mathrm{L}$. Moreover, the consumption of the different amino acids by the ferments with lower initial YAN was not significantly different. In contrast, commercial strain musts enriched with $250 \mathrm{mg} \mathrm{N} / \mathrm{L}$ YAN were characterized by the lowest utilization rate of leucine, valine, asparagine and glutamine, while the $\mathrm{Sb}$ strain presented the highest utilization rate for the same amino acids. The absence of 
statistically important differences in ferments with lower initial YAN could be attributed to a possible derepression of external hydrolytic enzymes involved in amino acid utilization (e.g., asparaginase) and/ or polymerization of metabolic enzymes responsible for the synthesis of amino acids, due to nitrogen starvation, leading to altered or secondary functions $[30,31]$. The differences noted for leucine, valine, asparagine and glutamine could be the consequence of the membrane structural disparities of the three yeasts, leading to alternate permease activity. More specifically, the enzymatic activity of Bap2 permease (responsible for leucine and valine transfer) and Agp1 (which transports asparagine and glutamine in the yeast cell) [32] excreted by Sb strain might be higher in comparison with the other yeasts strains examined. Asparagine utilization and fermentation kinetics were inversely proportional, while glutamine affected yeast growth indirectly through its connection with asparagine, providing evidence that asparagine supports yeast growth [33]. Leucine cannot provide any positive impact on yeast growth, as also verified by previous studies [32,33]. Fermentations carried out with Sa strain with a low initial level of YAN contained the highest concentration of total amino acids after 25 days of fermentation, most likely due to extended yeast cell autolysis [34]. Further investigation of mannoprotein concentration could substantiate this assumption. None of the three examined strains presented the ability to degrade proline (no statistical differences were observed compared to the initial concentration (data not shown)); however, arginine content of the final wines was statistically different depending on the strain (Table 2). Since both amino acids include the proline pathway for their conversion to glutamate and $\mathrm{NH}_{4}{ }^{+}$, arginine degradation probably followed the urea cycle [35,36]. Inhibition of arginine to proline utilization through Put 4 (the main transporter of proline uptake) and GAP1 endocytosis could also be another explanation [37]. The lower concentration of arginine in trials conducted with $\mathrm{Sb}$ compared to Sa strain could be explained through the more limited expression of URE2 protein, repressing the transcription of the genes responsible for proline, hence of arginine degradation under nitrogen catabolite repression [35].

Table 2. Concentration $(\mathrm{ng} / \mathrm{mL})$ of amino acids after 25 days of fermentation. Values followed by different letters in each column indicate significant differences $(p<0.05)$ among different samples.

\begin{tabular}{|c|c|c|c|c|c|c|}
\hline & Commercial & Sa & $\mathrm{Sb}$ & Commercial & Sa & $\mathrm{Sb}$ \\
\hline YAN & & $150 \mathrm{mg} \mathrm{N} / \mathrm{L}$ & & & $250 \mathrm{mg} \mathrm{N} / \mathrm{L}$ & \\
\hline $\begin{array}{l}\text { 4-Hydroxy- } \\
\text { Proline }\end{array}$ & $2.05 \pm 0.39^{a}$ & $1.54 \pm 0.31^{\mathrm{a}}$ & $1.92 \pm 0.39^{a}$ & $1.20 \pm 0.00^{\mathrm{a}}$ & $2.00 \pm 0.79^{a}$ & $2.02 \pm 0.41^{\mathrm{a}}$ \\
\hline Proline & $92.93 \pm 5.20^{a b}$ & $101.34 \pm 0.25^{\mathrm{ab}}$ & $91.82 \pm 0.80^{\mathrm{ab}}$ & $104.74 \pm 0.00^{\mathrm{a}}$ & $97.95 \pm 3.99 \mathrm{ab}$ & $87.79 \pm 2.49^{a b}$ \\
\hline Phenylalanine & $0.76 \pm 0.29^{a}$ & $0.19 \pm 0.02^{\mathrm{a}}$ & $2.02 \pm 0.26^{\mathrm{a}}$ & $1.07 \pm 0.04^{\mathrm{a}}$ & $1.00 \pm 0.10^{\mathrm{a}}$ & $0.80 \pm 0.00^{\mathrm{a}}$ \\
\hline Tyrosine & $0.05 \pm 0.01^{\mathrm{a}}$ & $0.54 \pm 0.05^{\mathrm{a}}$ & $0.24 \pm 0.02^{\mathrm{a}}$ & $0.77 \pm 0.01^{\mathrm{a}}$ & $0.30 \pm 0.03^{a}$ & $0.12 \pm 0.00^{\mathrm{a}}$ \\
\hline Aspartic acid & $1.33 \pm 0.10^{a}$ & $2.41 \pm 0.53^{a}$ & $1.95 \pm 0.3^{a}$ & $3.57 \pm 0.00^{a}$ & $2.45 \pm 0.50^{a}$ & $1.73 \pm 0.30^{\mathrm{a}}$ \\
\hline Glutamic acid & $0.95 \pm 0.08^{b}$ & $0.24 \pm 0.00^{b}$ & $3.02 \pm 0.84^{\mathrm{ab}}$ & $5.46 \pm 0.04^{\mathrm{ab}}$ & $5.54 \pm 0.19^{a b}$ & $9.26 \pm 0.65^{\mathrm{a}}$ \\
\hline Isoleucine & $0.54 \pm 0.04^{\mathrm{a}}$ & $0.26 \pm 0.03^{a}$ & $0.00 \pm 0.00^{\mathrm{a}}$ & $0.52 \pm 0.01^{\mathrm{a}}$ & $0.04 \pm 0.00^{\mathrm{a}}$ & $0.00 \pm 0.00^{\mathrm{a}}$ \\
\hline Tryptophane & $0.19 \pm 0.01^{\mathrm{a}}$ & $0.30 \pm 0.00^{\mathrm{a}}$ & $0.09 \pm 0.01^{\mathrm{a}}$ & $0.04 \pm 0.01^{\mathrm{a}}$ & $0.10 \pm 0.00^{\mathrm{a}}$ & $0.25 \pm 0.09^{a}$ \\
\hline Threonine & $2.51 \pm 0.01^{\mathrm{a}}$ & $1.73 \pm 0.05^{\mathrm{a}}$ & $1.18 \pm 0.07^{\mathrm{a}}$ & $1.26 \pm 0.00^{\mathrm{a}}$ & $0.61 \pm 0.06^{\mathrm{a}}$ & $0.94 \pm 0.03^{\mathrm{a}}$ \\
\hline Leucine & $0.57 \pm 0.03^{b}$ & $0.21 \pm 0.02^{b}$ & $0.13 \pm 0.01^{b}$ & $2.46 \pm 0.00^{\mathrm{a}}$ & $0.43 \pm 0.02^{b}$ & $0.55 \pm 0.04^{b}$ \\
\hline Valine & $1.38 \pm 0.02^{\mathrm{ab}}$ & $0.98 \pm 0.04^{\mathrm{ab}}$ & $0.45 \pm 0.02^{\mathrm{ab}}$ & $1.50 \pm 0.07^{\mathrm{a}}$ & $0.48 \pm 0.07^{\mathrm{ab}}$ & $0.30 \pm 0.01^{b}$ \\
\hline Serine & $1.11 \pm 0.03^{\mathrm{c}}$ & $1.24 \pm 0.03^{c}$ & $0.95 \pm 0.05^{\mathrm{c}}$ & $1.43 \pm 0.03^{b c}$ & $2.23 \pm 0.02^{\mathrm{a}}$ & $1.94 \pm 0.00^{\mathrm{ab}}$ \\
\hline Glutamine & $22.37 \pm 0.51^{\mathrm{ab}}$ & $68.30 \pm 0.25^{\mathrm{ab}}$ & $8.85 \pm 0.31^{b}$ & $22.87 \pm 0.00^{\mathrm{a}}$ & $50.66 \pm 0.20^{\mathrm{ab}}$ & $7.43 \pm 0.00^{b}$ \\
\hline Alanine & $17.72 \pm 0.73^{\mathrm{ab}}$ & $33.58 \pm 0.44^{\mathrm{ab}}$ & $4.87 \pm 0.31^{b}$ & $44.93 \pm 0.00^{\mathrm{a}}$ & $12.45 \pm 0.52^{b}$ & $15.86 \pm 0.00^{a b}$ \\
\hline Asparagine & $1.33 \pm 0.28^{b c}$ & $0.56 \pm 0.27^{\mathrm{c}}$ & $0.27 \pm 0.07^{c}$ & $10.34 \pm 0.00^{\mathrm{a}}$ & $2.45 \pm 0.32^{b}$ & $0.74 \pm 0.00^{\mathrm{c}}$ \\
\hline Glycine & $2.84 \pm 0.40 \mathrm{bc}$ & $2.49 \pm 0.10^{c}$ & $4.25 \pm 0.17^{\mathrm{ab}}$ & $5.41 \pm 0.30^{\mathrm{a}}$ & $5.54 \pm 0.44^{\mathrm{a}}$ & $5.04 \pm 0.00^{\mathrm{a}}$ \\
\hline Cysteine & $12.63 \pm 0.06^{\mathrm{a}}$ & $12.64 \pm 0.08^{a}$ & $12.56 \pm 0.01^{\mathrm{a}}$ & $12.54 \pm 0.00^{\mathrm{a}}$ & $12.58 \pm 0.03^{\mathrm{a}}$ & $12.60 \pm 0.06^{\mathrm{a}}$ \\
\hline Histidine & $1.72 \pm 0.34^{\mathrm{a}}$ & $1.77 \pm 0.29^{a}$ & $1.25 \pm 0.23^{a}$ & $2.01 \pm 0.08^{\mathrm{a}}$ & $1.93 \pm 0.44^{\mathrm{a}}$ & $1.75 \pm 0.00^{\mathrm{a}}$ \\
\hline Lysine & $12.73 \pm 0.30^{\mathrm{a}}$ & $12.89 \pm 0.46^{\mathrm{a}}$ & $13.47 \pm 1.01^{\mathrm{a}}$ & $15.19 \pm 0.00^{\mathrm{a}}$ & $12.91 \pm 0.49^{\mathrm{a}}$ & $13.08 \pm 0.28^{a}$ \\
\hline Arginine & $1.54 \pm 0.63^{c}$ & $6.35 \pm 0.45^{b}$ & $2.53 \pm 0.31^{c}$ & $9.18 \pm 0.00^{\mathrm{a}}$ & $5.99 \pm 0.96^{b}$ & $2.22 \pm 0.22^{c}$ \\
\hline Total & $191.24 \pm 5.22$ & $263.48 \pm 7.63$ & $165.77 \pm 3.01$ & $360.08 \pm 0.11$ & $231.59 \pm 6.71$ & $178.38 \pm 6.08$ \\
\hline
\end{tabular}




\subsection{Total Acidity and Production of Secondary Metabolites}

After the end of alcoholic fermentations, an average reduction of $20.1 \%$ in tartaric acid was observed (Table 3). No significant differences were observed between ferments containing different amounts of YAN. These results are in agreement with preview studies for S. cerevisiae and could be due to biochemical utilization or physical losses through decreased solubility or tartaric acid's adsorption to the surface of yeast cells [38]. Based on the absence of statistically important differences between different yeast strains, it is surmised that physiochemical phenomena have a greater impact on the alterations of tartaric acid concentrations.

Table 3. Chemical parameters of ferments after 25 days of fermentations with different $S$. cerevisiae strains. Values followed by different letters in each column indicate significant differences $(p<0.05)$ among different samples.

\begin{tabular}{|c|c|c|c|c|c|c|c|}
\hline \multirow[b]{2}{*}{ YAN (mg/L) } & \multirow{2}{*}{$\begin{array}{c}\text { Must } \\
80\end{array}$} & \multicolumn{2}{|c|}{ Commercial } & \multicolumn{2}{|c|}{$\mathrm{Sa}$} & \multicolumn{2}{|c|}{$\mathrm{Sb}$} \\
\hline & & 150 & 250 & 150 & 250 & 150 & 250 \\
\hline $\mathrm{EtOH} \%(v / v)$ & $0.00 \pm 0.00$ & $12.76 \pm 0.12^{a}$ & $12.91 \pm 0.01^{\mathrm{a}}$ & $13.10 \pm 0.08^{a}$ & $13.00 \pm 0.00^{a}$ & $12.82 \pm 0.00^{\mathrm{a}}$ & $12.81 \pm 0.17^{\mathrm{a}}$ \\
\hline $\mathrm{pH}$ & $3.15 \pm 0.01$ & $3.13 \pm 0.01^{a}$ & $3.14 \pm 0.00^{\mathrm{a}}$ & $3.09 \pm 0.01^{\mathrm{b}}$ & $3.09 \pm 0.01^{b}$ & $2.98 \pm 0.00^{\mathrm{c}}$ & $3.00 \pm 0.01^{c}$ \\
\hline $\begin{array}{l}\text { Total Acidity (g } \\
\text { tartaric acid/L) }\end{array}$ & $5.21 \pm 0.03$ & $7.84 \pm 0.03^{b}$ & $7.68 \pm 0.02^{b}$ & $7.39 \pm 0.03^{c}$ & $7.50 \pm 0.03^{c}$ & $8.67 \pm 0.02^{\mathrm{a}}$ & $8.56 \pm 0.06^{\mathrm{a}}$ \\
\hline $\begin{array}{c}\text { Volatile Acidity } \\
\text { (g acetic } \\
\text { acid/L) }\end{array}$ & $0.30 \pm 0.01$ & $0.53 \pm 0.02^{\mathrm{a}}$ & $0.53 \pm 0.00^{\mathrm{a}}$ & $0.37 \pm 0.01^{b}$ & $0.40 \pm 0.01^{\mathrm{b}}$ & $0.31 \pm 0.01^{\mathrm{c}}$ & $0.32 \pm 0.02^{c}$ \\
\hline $\begin{array}{l}\text { Residual Sugar } \\
(\mathrm{g} / \mathrm{L})\end{array}$ & $210.05 \pm 2.1$ & $5.05 \pm 1.9^{a}$ & $3.95 \pm 0.3^{a}$ & $3.70 \pm 1.4^{\mathrm{a}}$ & $3.65 \pm 0.4^{\mathrm{a}}$ & $3.65 \pm 0.2^{\mathrm{a}}$ & $4.35 \pm 1.3^{\mathrm{a}}$ \\
\hline Glycerol (g/L) & $0.00 \pm 0.00$ & $6.25 \pm 0.15^{a b c}$ & $6.00 \pm 0.00 \mathrm{bcd}$ & $5.75 \pm 0.15^{\mathrm{cd}}$ & $5.55 \pm 0.05^{\mathrm{d}}$ & $6.75 \pm 0.15^{\mathrm{a}}$ & $6.50 \pm 0.00^{\mathrm{ab}}$ \\
\hline Tartaric (g/L) & $6.75 \pm 0.1$ & $5.4 \pm 0.1^{\mathrm{abc}}$ & $5.2 \pm 0.0^{c}$ & $5.3 \pm 0.1^{b c}$ & $5.3 \pm 0.0^{b c}$ & $5.6 \pm 0.1^{\mathrm{a}}$ & $5.5 \pm 0.1^{\mathrm{ab}}$ \\
\hline Citric (mg/L) & $720 \pm 0.0$ & $180.0 \pm 0.0^{b}$ & $185.0 \pm 0.0^{b}$ & $190.0 \pm 0.0^{b}$ & $170.0 \pm 0.0^{\mathrm{b}}$ & $365.0 \pm 0.0^{\mathrm{a}}$ & $385.0 \pm 0.0^{\mathrm{a}}$ \\
\hline
\end{tabular}

There were no differences in malic acid concentrations, nor was any lactic acid production noted (data not shown) even when, in some cases, an up to $22 \%$ consumption of malic acid could be observed, being mainly strain-dependent $[38,39]$. The ability to metabolize extracellular malic acid depends on an efficient system for malic acid transport (i.e., active import via a malate transporter) and a malic acid converting enzyme [40] that seemed to be absent in the investigated strains.

Reduction in citric acid concentration was also observed (Table 3). Fermentations carried out with the commercial, Sa and Sb strains presented a $74.5 \%, 74.8 \%$ and $47.6 \%$ reduction in citric acid content, respectively. Overexpression of CIT1 and CIT3 genes encoding mitochondrial citrate synthase, which catalyzes the first step in the tricarboxylic acid (TCA) pathway, and/or of the KGD1, KGD2 and LPD1 genes encoding the oxoglutarate dehydrogenase (OGDH) complex, which helps the formation of succinic acid and fumaric acid in commercial and Sa strains, could be a possible explanation for these results [29]. Absence of significant differences between ferments of the same strain with different YAN contents, constitutes indication of suppressed expression of GLN3 and URE2 genes associated with alternative nitrogen assimilatory pathways connected with the TCA cycle [35]. The more limited alterations in citric acid concentration in ferments carried out with $\mathrm{Sb}$ strain led to higher total acidity (TA) and lower $\mathrm{pH}$, compared to wines fermented with the commercial and Sa strains. The observed relatively high TA (and low $\mathrm{pH}$ ), were within the range commonly measured in wines produced from Assyrtiko grapes [41].

Apart from the higher TA values, a more moderated increase in volatile acidity (VA) was also achieved in Sb wines compared to the commercial and Sa wines (Table 3). These results are in line with previous works that demonstrated a positive correlation between acetic acid and glycerol production. As reported by Romano et al., 1994, the production of acetaldehyde and consequently, the production of acetic acid and other compounds such as acetoin and higher alcohols, is mainly strain-dependent [42]. The different strains examined could be categorized according to phenotypes as low, medium and high acetaldehyde producers, respectively. Moreover, accumulation of acetic acid in fermentations carried 
out with the commercial strain, with the possibly suppressed expression of HAA1 gene (responsible for the adaptation of yeast cells upon exposure to toxic concentrations of acetic acid), could have led to decreased cell viability and retarded fermentations $[43,44]$. In addition, a slightly higher (however, not significantly important) increase in VA was observed in fermentations with $250 \mathrm{mg} \mathrm{N} / \mathrm{L}$ compared to those with $150 \mathrm{mg}$ N/L YAN, when carried out with the commercial and Sb strains, unlike with the Sa strain. Different research groups have proposed that acetic acid production is negatively correlated with nitrogen content; however, this was not observed for acetic acid content for the commercial and $\mathrm{Sb}$ strains [10,45]. Considering, though, the strain-dependent manner of acetic acid production and the absence of statistically important differences between ferments with discrete YAN concentrations, these results could be explained.

Glycerol is a significant by-product of alcoholic fermentation, as it contributes to the organoleptic properties of wine, increasing viscosity and sweetness [46]. In the current study, the highest production of glycerol was observed in musts containing $150 \mathrm{mg} \mathrm{N} / \mathrm{L}$ YAN, for all examined S. cerevisiae strains (Table 3). These results are in agreement with previews studies, suggesting that nitrogen limitation increases glycerol production [45,47]. Independently from the YAN level, glycerol concentrations ranged between $5.8-6.8 \mathrm{~g} / \mathrm{L}$, which was within the range of previously reported data (4.2-10.4 g/L) [45,47-50]. However, the $\mathrm{Sb}$ strain was characterized by the highest glycerol and lower ethanol production, although the differences observed were not statistically significant. Such differentiations between strains regarding glycerol production could be attributed to the differences between the two pathways that are linked to glycerol formation. The low and high glycerol producing strains differ in glycerol-3-phosphate dehydrogenase activity. The gapN gene that encodes non-phosphorylating $\mathrm{NADP}^{+}$is responsible for the enzymatic activity, and in strains where this gene is suppressed, ethanol production is lower, while glycerol yield is higher. Higher production of glycerol by the $\mathrm{Sb}$ strain could also be ascribed to the suppressed expression of the mhpF gene encoding acetylating NAD+ linked to acetaldehyde dehydrogenase and overexpression of the frdA gene encoding NAD+ linked to fumarate reductase [51]. Furthermore, the three strains presented different production kinetics (Figure 5). Glycerol production could be related to glucose consumption, since glycerol reached a plateau when glucose was exhausted. Aerobic production of glycerol in the presence of glucose, which may result in respiro-fermentative growth, is a possible explanation for the results observed [52].

\subsection{Volatile Composition}

Analysis of volatile compounds was performed by SPME GC/MS targeting to evaluate the volatile characteristics of wines produced by the two wild type yeast strains and compared with the commercial one (Figure 6). In line with the more limited increase in $\mathrm{VA}, \mathrm{Sb}$ media were characterized by considerably higher production of higher alcohols and ketones compared to commercial and Sa media (Figure 6a,b). According to the results, it was observed that the lower the nitrogen content, the lower the production of higher alcohols in wine. However, as far as Sb strain is concerned, the opposite was observed. A possible explanation for this could be a better utilization of valine by this strain that intensifies the production of fusel alcohols $[10,42,53,54]$. The Sa and commercial strains produced similar contents of higher alcohols regardless of nitrogen content. Moreover, the Sb strain produced 1.9-fold higher amounts of alcohols and 5.6-fold higher amounts of ketones compared to the commercial strain; however, no significant differences were observed between Sa and the commercial strain. These results highlight the variations that might occur in the metabolic pathways of different yeast strains. The increased production of higher alcohols by the $\mathrm{Sb}$ strain evinces a less efficient uptake of nitrogen, as previously reported [55]. 


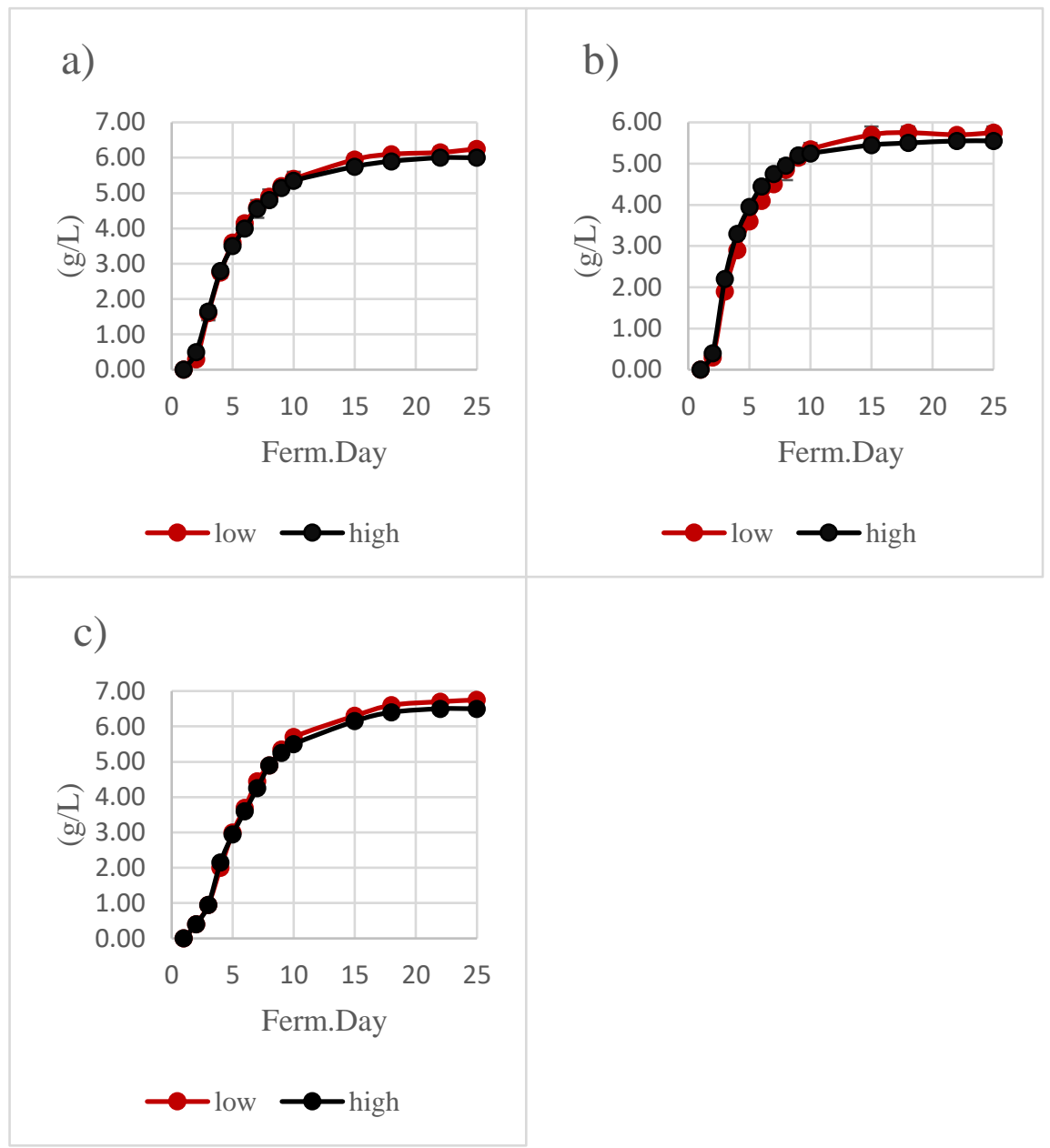

Figure 5. Production of glycerol by S. cerevisiae in fermentations with (a) commercial, (b) Sa and (c) Sb strains. Red and black lines correspond to samples fermented with low and high initial concentrations of YAN, respectively.

Furthermore, the Sb strain produced less fatty acids and esters compared to the other two strains, probably as a defensive mechanism to toxic 'metabolic waste' (Figure 6c,d) [55]. Lower concentrations of fatty acids could be linked to lower concentrations of acylcoenzyme A (CoA), one of the factors that is directly related to ester production [56]. Deficient amounts of acyl-CoA could also result in lower concentrations of acetyl-coenzyme A (CoA), suppressing the TCA cycle in the Sb strain, as has been previously documented. Reduced activity of enzymes involved in the synthesis (alcohol acetyl transferases I and II) and hydrolysis (esterases) of esters in Sb media could be responsible for the insufficient ester production compared to the commercial and Sa wines. Lower expression of ATF1 and ATF2 genes encoding alcohol acetyl transferases I and II and overexpression of the IAH1 gene encoding ester degrading enzyme could be another possible explanation [56]. In addition, lower concentrations of esters in $\mathrm{Sb}$ wines could be linked to leucine consumption [57]. As far as the different initial YAN contents are concerned, the three strains showed different patterns of ester and fatty acid production. In media with $150 \mathrm{mg} \mathrm{N} / \mathrm{L}$, the commercial and Sa strains resulted in lower amounts of fatty acids and higher amounts of esters compared to the wines containing $250 \mathrm{mg} \mathrm{N} / \mathrm{L}$. For the commercial strain, ester production was proportional to initial YAN. 


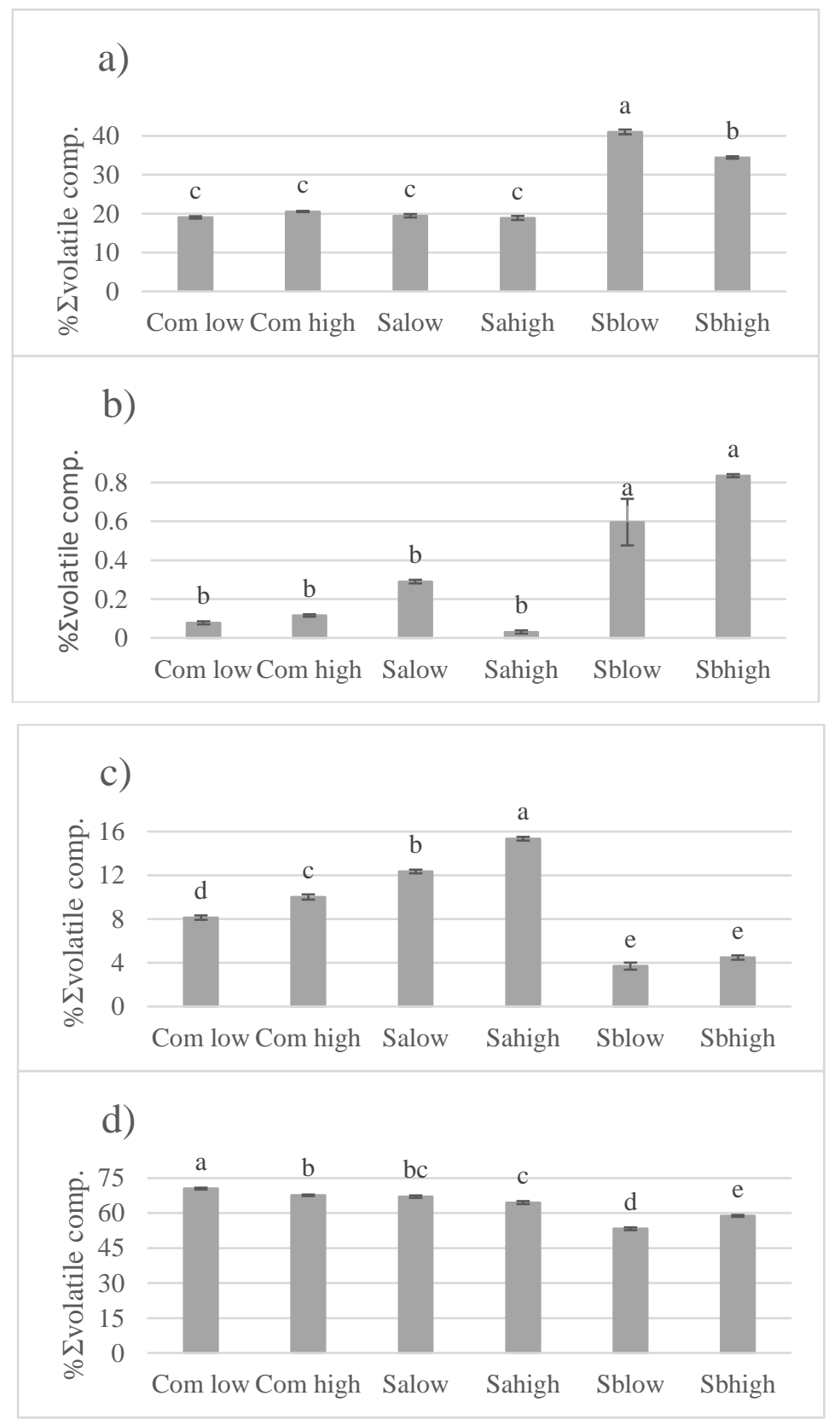

Figure 6. \% Concentrations of the most important groups of volatile compounds: (a) higher alcohols, (b) ketones, (c) fatty acids and (d) esters. The 'com', 'Sa' and 'Sb' correspond to fermentations carried out with the commercial, $\mathrm{Sa}$ and $\mathrm{Sb}$ strains, respectively. Values followed by different letters in each column indicate significant differences $(p<0.05)$ among different samples.

\subsection{Sensory Analysis}

The results of sensory analysis did not show any significant differences concerning color intensity, indicating that the judges could not perceive any differences in color intensity among the pivot (control wine fermented with the commercial S. cerevisiae strain) and the rest of the samples (Figure 7). The results are in agreement with the results obtained for low molecular weight phenolic compounds and absorption at $420 \mathrm{~nm}$ (data not shown), with no statistically important differences observed among the samples. Moreover, in line with the results regarding VA, the $\mathrm{Sa}$ and $\mathrm{Sb}$ wines were clearly judged as less vinegary and oxidized, since the negative frequencies for these attributes were higher than the positives. The same wines were also judged as less reductive than the pivot, probably due to lower production of volatile sulfurous compounds [58]. Further investigation in this group of 
volatile compounds is needed to support this assumption. Regarding floral attributes, the positive frequencies for the $\mathrm{Sb}$ strain were higher than the negative, indicating this wine was clearly judged as more floral than the pivot, while for the commercial strain, positive and negative frequencies were equal, showing similar floral notes with the pivot. These results are in line with the results obtained by GC-MS analysis regarding the contents of higher alcohols and ketones that are responsible for the floral and green aromas [4,59]. Wines fermented with the Sa strain were also characterized as more fruity than the pivot, probably due to the higher production of esters (Figure 7). Surprisingly, Sb wines were also characterized as more fruity even though their ester content was lower than that of the pivot, highlighting the importance of wine matrix in the perception of unique aromas. In addition, the overall aroma of the samples was judged as more pleasant than that of the pivot. Moreover, for wines fermented with the Sa and Sb strains, the positive frequencies for acidity were higher than the negatives. This was expected for the $\mathrm{Sb}$ wines due to the higher TA and lower $\mathrm{pH}$, but not for Sa. The higher acidity rating of the Sa wine could be attributed to the lower concentration of residual sugars compared with the control, since they could also affect the perception of acidity [60]. The higher concentration of residual sugars in control samples probably affected the mouthfeel perception as well, since pivot was characterized as poorer than $\mathrm{Sb}$ and similar to Sa based on this attribute. The lower concentration of asparagine observed in $\mathrm{Sb}$ samples could also be another possible explanation for the observed lower ratings of mouthfeel, since this amino acid is positively related with mannoprotein production in wine [61]. Further investigation into mannoprotein production from the three strains is necessary to support this assumption.

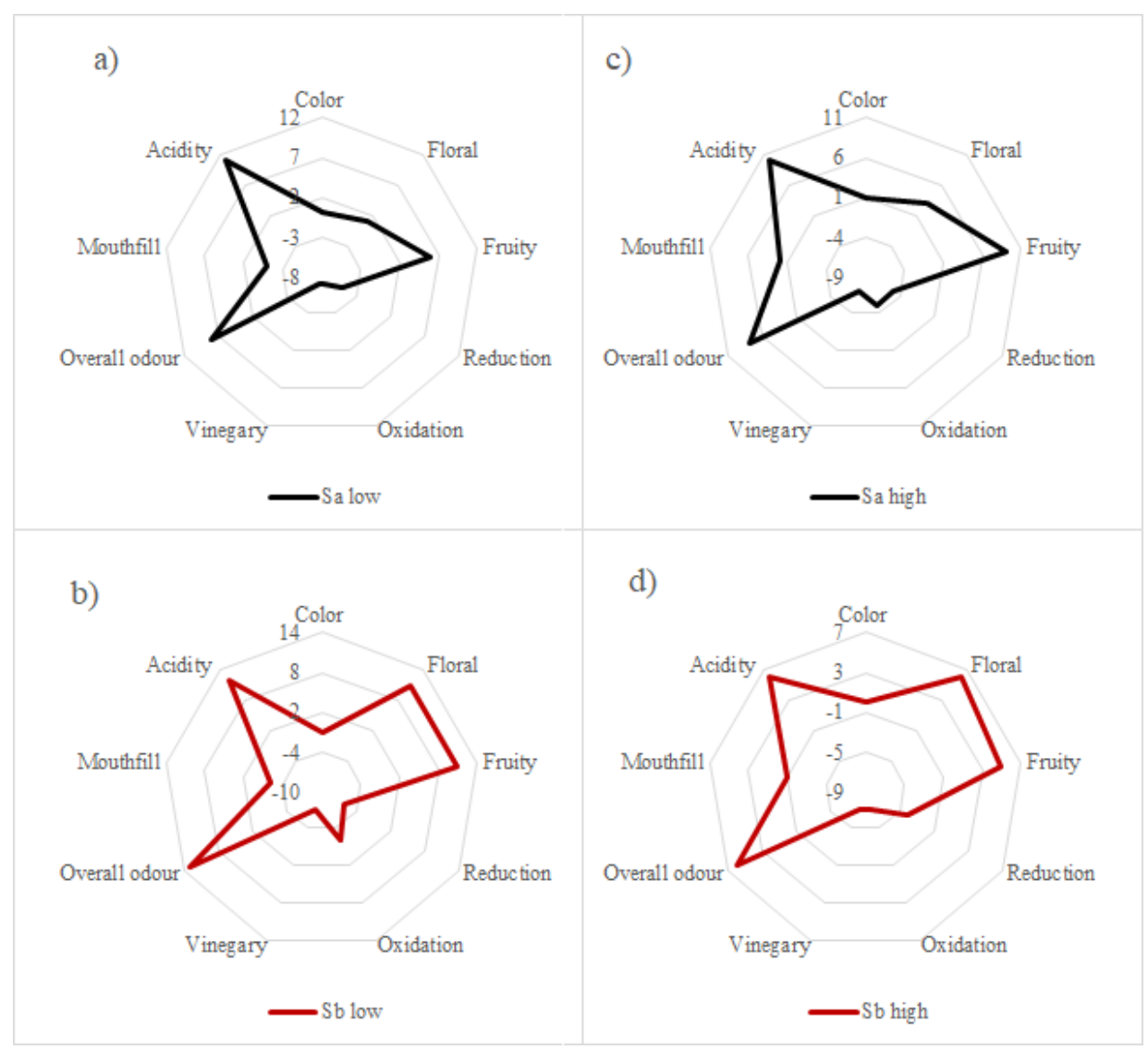

Figure 7. Pivot organoleptic analysis for samples fermented with (a) Sa strain and $150 \mathrm{mg} / \mathrm{L}$ initial YAN, (b) Sb strain and $150 \mathrm{mg} / \mathrm{L}$ initial YAN, (c) Sa strain and $250 \mathrm{mg} / \mathrm{L}$ initial YAN and (d) Sb strain and $250 \mathrm{mg} / \mathrm{L}$ YAN. 


\section{Conclusions}

The three S. cerevisiae strains were characterized by different nitrogen $\left(\mathrm{NH}_{4}{ }^{+}\right.$and $\mathrm{N} \alpha$-amino acid) depletion rates in Assyrtiko must fermentation, resulting in different fermentation kinetics, production of secondary compounds, and eventually in different sensory profiles for each wine. Initial YAN concentration had a greater impact on the volatile profile of the produced wines. The organoleptic profile of Assyrtiko wine could be modulated, based on consumer preferences, by selecting the specific strain and the initial YAN content. The new indigenous strains examined seem to have the potential to be involved in large-scale wine production substituting the commercial strain, since they were characterized by lower VA and vinegary and oxidation scores and higher quality of overall aroma assessment. More specifically, the Sa strain combined with $150 \mathrm{mg} \mathrm{N} / \mathrm{L}$ initial YAN could result in Assyrtiko wines with enhanced fruity character and body due to higher production of esters and glycerol, respectively. If a more floral profile with higher concentrations of higher alcohols is preferred, then the Sb strain with $250 \mathrm{mg}$ N/L of initial YAN would be more suitable. Even though the production of glycerol in this case is more limited, the VA is lower and both higher alcohol and ester concentrations are higher.

Author Contributions: Conceptualization, S.C. and S.K.; methodology, S.C., M.D. and S.K.; software, S.C. and S.K.; validation, S.C., S.P., M.D., A.T., I.B.C., V.C. and S.K.; formal analysis, S.C., M.D., A.T. and I.B.C.; investigation, S.C. and S.K.; resources, S.C. and S.K.; data curation, S.C. and S.K.; writing-original draft preparation, S.C., A.T. and S.K..; writing-review and editing, S.C., S.P., M.D., A.T., I.B.C., V.C and S.K.; visualization, S.C. and M.D.; supervision, S.C.; project administration, S.C.; funding acquisition, S.P. and S.K. All authors have read and agreed to the published version of the manuscript.

Funding: The current investigation was financially supported by the project titled "Exploitation of new natural microbial flora from Greek origin amenable for the production of high-quality wines" (Acronym: Oenovation, project code T1EDK-04747) financed by the Ministry of National Education and Religious Affairs, Greece (project action: "Investigate-Create-Innovate 2014-2020, Intervention $\left.\mathrm{II}^{\prime \prime}\right)$.

Institutional Review Board Statement: The study was conducted according to the guidelines of the Declaration of Helsinki. Ethical review and approval for this study were waived due to the anonymity of the interviews and the request for non-sensitive information.

Informed Consent Statement: Panelists gave informed consent before participating in this study.

Data Availability Statement: The data presented in this study are available on request from the corresponding author (pending privacy and ethical considerations).

Acknowledgments: The authors gratefully acknowledge 'Santo Wines' for grape supplementation.

Conflicts of Interest: The authors declare no conflict of interest. The funders had no role in the design of the study; in the collection, analyses, or interpretation of data; in the writing of the manuscript, or in the decision to publish the results.

\section{References}

1. Rabadán, A. Consumer attitudes towards technological innovation in a traditional food product: The case of wine. Foods 2021, 10, 1363. [CrossRef] [PubMed]

2. Deroover, K.; Siegrist, M.; Brain, K.; McIntyre, J.; Bucher, T. A scoping review on consumer behaviour related to wine and health. Trends Food Sci. Technol. 2021, 112, 559-580. [CrossRef]

3. Capitello, R.; Agnoli, L.; Charters, S.; Begalli, D. Labelling environmental and terroir attributes: Young Italian consumers' wine preferences. J. Clean. Prod. 2021, 304, 126991. [CrossRef]

4. Terpou, A.; Ganatsios, V.; Kanellaki, M.; Koutinas, A.A. Entrapped psychrotolerant yeast cells within pine sawdust for low temperature wine making: Impact on wine quality. Microorganisms 2020, 8, 764. [CrossRef]

5. Su, Y.; Macías, L.G.; Heras, J.M.; Querol, A.; Guillamón, J.M. Phenotypic and genomic differences among $S$. cerevisiae strains in nitrogen requirements during wine fermentations. Food Microbiol. 2021, 96, 103685. [CrossRef]

6. Wiles, A.M.; Cai, H.; Naider, F.; Becker, J.M. Nutrient regulation of oligopeptide transport in Saccharomyces cerevisiae. Microbiology 2006, 152, 3133-3145. [CrossRef] 
7. Verdenal, T.; Dienes-Nagy, Á.; Spangenberg, J.E.; Zufferey, V.; Spring, J.-L.; Viret, O.; Marin-Carbonne, J.; van Leeuwen, C. Understanding and managing nitrogen nutrition in grapevine: A review. OENO One 2021, 55, 1-43. [CrossRef]

8. Gobert, A.; Tourdot-Maréchal, R.; Sparrow, C.; Morge, C.; Alexandre, H. Influence of nitrogen status in wine alcoholic fermentation. Food Microbiol. 2019, 83, 71-85. [CrossRef]

9. Belda, I.; Gobbi, A.; Ruiz, J.; de Celis, M.; Ortiz-Álvarez, R.; Acedo, A.; Santos, A. 3.32-Microbiomics to define wine terroir. In Comprehensive Foodomics; Cifuentes, A., Ed.; Elsevier: Oxford, UK, 2021; pp. 438-451.

10. Bely, M.; Rinaldi, A.; Dubourdieu, D. Influence of assimilable nitrogen on volatile acidity production by Saccharomyces cerevisiae during high sugar fermentation. J. Biosci. Bioeng. 2003, 96, 507-512. [CrossRef]

11. Lytra, G.; Miot-Sertier, C.; Moine, V.; Coulon, J.; Barbe, J.-C. Influence of must yeast-assimilable nitrogen content on fruity aroma variation during malolactic fermentation in red wine. Food Res. Int. 2020, 135, 109294. [CrossRef]

12. Vilanova, M.; Siebert, T.E.; Varela, C.; Pretorius, I.S.; Henschke, P.A. Effect of ammonium nitrogen supplementation of grape juice on wine volatiles and non-volatiles composition of the aromatic grape variety Albariño. Food Chem. 2012, 133, 124-131. [CrossRef]

13. Rollero, S.; Bloem, A.; Brand, J.; Ortiz-Julien, A.; Camarasa, C.; Divol, B. Nitrogen metabolism in three non-conventional wine yeast species: A tool to modulate wine aroma profiles. Food Microbiol. 2021, 94, 103650. [CrossRef] [PubMed]

14. Vilanova, M.; Pretorius, I.S.; Henschke, P.A. Chapter 58-Influence of diammonium phosphate addition to fermentation on wine biologicals. In Processing and Impact on Active Components in Food; Preedy, V., Ed.; Academic Press: San Diego, CA, USA, 2015; pp. 483-491.

15. Tzamourani, A.P.; Di Napoli, E.; Paramithiotis, S.; Oikonomou-Petrovits, G.; Panagiotidis, S.; Panagou, E.Z. Microbiological and physicochemical characterisation of green table olives of Halkidiki and Conservolea varieties processed by the Spanish method on industrial scale. Int. J. Food Sci. Technol. 2021, 56, 3845-3857. [CrossRef]

16. Terpou, A.; Dimopoulou, M.; Belka, A.; Kallithraka, S.; Nychas, G.-J.E.; Papanikolaou, S. Effect of myclobutanil pesticide on the physiological behavior of two newly isolated saccharomyces cerevisiae strains during very-high-gravity alcoholic fermentation. Microorganisms 2019, 7, 666. [CrossRef] [PubMed]

17. Dukes, B.C.; Butzke, C.E. Rapid determination of primary amino acids in grape juice using an o-Phthaldialdehyde/N-Acetyl-Lcysteine spectrophotometric assay. Am. J. Enol. Vitic. 1998, 49, 125-134.

18. Petropoulos, S.; Kanellopoulou, A.; Paraskevopoulos, I.; Kotseridis, Y.; Kallithraka, S. Characterization of grape and wine proanthocyanidins of Agiorgitiko (Vitis vinifera L. cv.) cultivar grown in different regions of Nemea. J. Food Compos. Anal. 2017, 63, 98-110. [CrossRef]

19. International Organisation of Vine and Wine. Compendium of International Methods of Wine and Must Analysis; OIV: Paris, France, 2020.

20. Aerny, J. Composés azotés des moûts et vins. Rev. Suisse Vitic. Arboric. Hortic. 1996, 28, 161-165.

21. Plioni, I.; Bekatorou, A.; Terpou, A.; Mallouchos, A.; Plessas, S.; Koutinas, A.; Katechaki, E. Vinegar production from corinthian currants finishing side-stream: Development and comparison of methods based on immobilized acetic acid Bacteria. Foods 2021, 10, 3133. [CrossRef]

22. Plioni, I.; Bekatorou, A.; Mallouchos, A.; Kandylis, P.; Chiou, A.; Panagopoulou, E.A.; Dede, V.; Styliara, P. Corinthian currants finishing side-stream: Chemical characterization, volatilome, and valorisation through wine and baker's yeast productiontechnoeconomic evaluation. Food Chem. 2021, 342, 128161. [CrossRef]

23. Thuillier, B.; Valentin, D.; Marchal, R.; Dacremont, C. Pivot $\odot$ profile: A new descriptive method based on free description. Food Qual. Prefer. 2015, 42, 66-77. [CrossRef]

24. Walker, G.M.; Stewart, G.G. Saccharomyces cerevisiae in the Production of fermented beverages. Beverages 2016, 2, 30. [CrossRef]

25. Liszkowska, W.; Berlowska, J. Yeast fermentation at low temperatures: Adaptation to changing environmental conditions and formation of volatile compounds. Molecules 2021, 26, 1035. [CrossRef] [PubMed]

26. Orlowski, J.H.; Barford, J.P. The mechanism of uptake of multiple sugars by Saccharomyces cerevisiae in batch culture under fully aerobic conditions. Appl. Microbiol. Biotechnol. 1987, 25, 459-463. [CrossRef]

27. Palma, M.; Madeira, S.C.; Mendes-Ferreira, A.; Sá-Correia, I. Impact of assimilable nitrogen availability in glucose uptake kinetics in Saccharomyces cerevisiae during alcoholic fermentation. Microb. Cell Factories 2012, 11, 99. [CrossRef] [PubMed]

28. Martínez-Moreno, R.; Morales, P.; Gonzalez, R.; Mas, A.; Beltran, G. Biomass production and alcoholic fermentation performance of Saccharomyces cerevisiae as a function of nitrogen source. FEMS Yeast Res. 2012, 12, 477-485. [CrossRef]

29. Camarasa, C.; Grivet, J.-P.; Dequin, S. Investigation by 13C-NMR and tricarboxylic acid (TCA) deletion mutant analysis of pathways for succinate formation in Saccharomyces cerevisiae during anaerobic fermentation. Microbiology 2003, 149, 2669-2678. [CrossRef]

30. Dunlop, P.C.; Roon, R.J.; Even, H.L. Utilization of D-asparagine by Saccharomyces cerevisiae. J. Bacteriol. 1976, 125, 999-1004. [CrossRef]

31. Noree, C.; Sirinonthanawech, N.; Wilhelm, J.E. Saccharomyces cerevisiae ASN1 and ASN2 are asparagine synthetase paralogs that have diverged in their ability to polymerize in response to nutrient stress. Sci. Rep. 2019, 9, 278. [CrossRef]

32. Schreve, J.L.; Sin, J.K.; Garrett, J.M. The Saccharomyces cerevisiae YCC5 (YCL025c) gene encodes an amino acid permease, Agp1, which transports asparagine and glutamine. J. Bacteriol. 1998, 180, 2556-2559. [CrossRef]

33. Fairbairn, S.; McKinnon, A.; Musarurwa, H.T.; Ferreira, A.C.; Bauer, F.F. The impact of single amino acids on growth and volatile aroma production by Saccharomyces cerevisiae Strains. Front. Microbiol. 2017, 8, 2554. [CrossRef] 
34. Martínez-Rodríguez, A.J.; Polo, M.C. Characterization of the nitrogen compounds released during yeast autolysis in a model wine system. J. Agric. Food Chem. 2000, 48, 1081-1085. [CrossRef] [PubMed]

35. Salmon, J.-M.; Barre, P. Improvement of nitrogen assimilation and fermentation kinetics under enological conditions by derepression of alternative nitrogen-assimilatory pathways in an industrial Saccharomyces cerevisiae strain. Appl. Environ. Microbiol. 1998, 64, 3831-3837. [CrossRef] [PubMed]

36. Martin, O.; Brandriss, M.C.; Schneider, G.; Bakalinsky, A.T. Improved anaerobic use of arginine by Saccharomyces cerevisiae. Appl. Environ. Microbiol. 2003, 69, 1623-1628. [CrossRef]

37. Nishimura, A.; Tanahashi, R.; Takagi, H. The yeast $\alpha$-arrestin Art3 is a key regulator for arginine-induced endocytosis of the high-affinity proline transporter Put4. Biochem. Biophys. Res. Commun. 2020, 531, 416-421. [CrossRef] [PubMed]

38. Benito, S.; Palomero, F.; Morata, A.; Calderón, F.; Palmero, D.; Suárez-Lepe, J.A. Physiological features of Schizosaccharomyces pombe of interest in making of white wines. Eur. Food Res. Technol. 2013, 236, 29-36. [CrossRef]

39. Del Mónaco, S.; Barda, N.; Rubio, N.; Caballero, A. Selection and characterization of a Patagonian Pichia kudriavzevii for wine deacidification. J. Appl. Microbiol. 2014, 117, 451-464. [CrossRef]

40. Redzepovic, S.; Orlic, S.; Majdak, A.; Kozina, B.; Volschenk, H.; Viljoen-Bloom, M. Differential malic acid degradation by selected strains of Saccharomyces during alcoholic fermentation. Int. J. Food Microbiol. 2003, 83, 49-61. [CrossRef]

41. Kechagia, D.; Paraskevopoulos, Y.; Symeou, E.; Galiotou-Panayotou, M.; Kotseridis, Y. Influence of prefermentative treatments to the major volatile compounds of Assyrtiko wines. J. Agric. Food Chem. 2008, 56, 4555-4563. [CrossRef]

42. Romano, P.; Suzzi, G.; Turbanti, L.; Polsinelli, M. Acetaldehyde production in Saccharomyces cerevisiae wine yeasts. FEMS Microbiol. Lett. 1994, 118, 213-218. [CrossRef]

43. Giannattasio, S.; Guaragnella, N.; Ždralević, M.; Marra, E. Molecular mechanisms of Saccharomyces cerevisiae stress adaptation and programmed cell death in response to acetic acid. Front. Microbiol. 2013, 4, 33. [CrossRef]

44. Mira, N.P.; Becker, J.D.; Sá-Correia, I. Genomic expression program involving the Haa1p-regulon in Saccharomyces cerevisiae response to acetic acid. OMICS A J. Integr. Biol. 2010, 14, 587-601. [CrossRef] [PubMed]

45. Vilanova, M.; Ugliano, M.; Varela, C.; Siebert, T.; Pretorius, I.S.; Henschke, P.A. Assimilable nitrogen utilisation and production of volatile and non-volatile compounds in chemically defined medium by Saccharomyces cerevisiae wine yeasts. Appl. Microbiol. Biotechnol. 2007, 77, 145-157. [CrossRef]

46. Yanniotis, S.; Kotseridis, G.; Orfanidou, A.; Petraki, A. Effect of ethanol, dry extract and glycerol on the viscosity of wine. J. Food Eng. 2007, 81, 399-403. [CrossRef]

47. Brandberg, T.; Gustafsson, L.; Franzén, C.J. The impact of severe nitrogen limitation and microaerobic conditions on extended continuous cultivations of Saccharomyces cerevisiae with cell recirculation. Enzym. Microb. Technol. 2007, 40, 585-593. [CrossRef]

48. Benito, Á.; Calderón, F.; Palomero, F.; Benito, S. Quality and composition of Airén wines fermented by sequential inoculation of Lachancea thermotolerans and Saccharomyces cerevisiae. Food Technol. Biotechnol. 2016, 54, 135-144. [CrossRef]

49. Englezos, V.; Rantsiou, K.; Cravero, F.; Torchio, F.; Ortiz-Julien, A.; Gerbi, V.; Rolle, L.; Cocolin, L. Starmerella bacillaris and Saccharomyces cerevisiae mixed fermentations to reduce ethanol content in wine. Appl. Microbiol. Biotechnol. 2016, 100, 5515-5526. [CrossRef]

50. Loira, I.; Morata, A.; Comuzzo, P.; Callejo, M.J.; González, C.; Calderón, F.; Suárez-Lepe, J.A. Use of Schizosaccharomyces pombe and Torulaspora delbrueckii strains in mixed and sequential fermentations to improve red wine sensory quality. Food Res. Int. 2015, 76, 325-333. [CrossRef]

51. Zhang, L.; Tang, Y.; Guo, Z.-P.; Ding, Z.-Y.; Shi, G.-Y. Improving the ethanol yield by reducing glycerol formation using cofactor regulation in Saccharomyces cerevisiae. Biotechnol. Lett. 2011, 33, 1375-1380. [CrossRef] [PubMed]

52. Scanes, K.; Hohrnann, S.; Prior, B. Glycerol production by the yeast Saccharomyces cerevisiae and its relevance to wine. S. Afr. J. Enol. Vitic. 1998, 19, 17-24. [CrossRef]

53. Clement, T.; Perez, M.; Mouret, J.R.; Sanchez, I.; Sablayrolles, J.M.; Camarasa, C. Metabolic responses of Saccharomyces cerevisiae to valine and ammonium pulses during four-stage continuous wine fermentations. Appl. Environ. Microbiol. 2013, 79, $2749-2758$. [CrossRef] [PubMed]

54. Derrick, S.; Large, P.J. Activities of the enzymes of the Ehrlich pathway and formation of branched-chain alcohols in Saccharomyces cerevisiae and Candida utilis grown in continuous culture on valine or ammonium as sole nitrogen source. J. Gen. Microbiol. 1993, 139, 2783-2792. [CrossRef] [PubMed]

55. Carrau, F.M.; Medina, K.; Farina, L.; Boido, E.; Henschke, P.A.; Dellacassa, E. Production of fermentation aroma compounds by Saccharomyces cerevisiae wine yeasts: Effects of yeast assimilable nitrogen on two model strains. FEMS Yeast Res. 2008, 8, 1196-1207. [CrossRef] [PubMed]

56. Saerens, S.M.G.; Delvaux, F.R.; Verstrepen, K.J.; Thevelein, J.M. Production and biological function of volatile esters in Saccharomyces cerevisiae. Microb. Biotechnol. 2010, 3, 165-177. [CrossRef] [PubMed]

57. Gobert, A.; Tourdot-Maréchal, R.; Morge, C.; Sparrow, C.; Liu, Y.; Quintanilla-Casas, B.; Vichi, S.; Alexandre, H. Non-Saccharomyces Yeasts Nitrogen Source Preferences: Impact on Sequential Fermentation and Wine Volatile Compounds Profile. Front. Microbiol. 2017, 8, 2175. [CrossRef] [PubMed]

58. Müller, N.; Rauhut, D. Recent developments on the origin and nature of reductive sulfurous off-odours in wine. Fermentation 2018, 4, 62. [CrossRef] 
59. Furdíková, K.; MakyŠová, K.; Špánik, I. Effect of indigenous S. cerevisiae strains on higher alcohols, volatile acids and esters in wine. Czech J. Food Sci. 2017, 35, 131-142. [CrossRef]

60. Noordeloos, S.; Nagel, C.W. Effect of Sugar on Acid Perception in Wine. Am. J. Enol. Vitic. 1972, 23, $139-143$.

61. Barnes, G.; Hansen, W.J.; Holcomb, C.L.; Rine, J. Asparagine-linked glycosylation in Saccharomyces cerevisiae: Genetic analysis of an early step. Mol. Cell. Biol. 1984, 4, 2381-2388. [CrossRef] 